JKEP

Vol 5, No 2, November 2020

ISSN: 2354-6042 (Print)

ISSN : 2354-6050 (Online)

\title{
Hubungan Kecemasan dengan Pola Tidur Lansia Hipertensi dan Tidak Hipertensi
}

\author{
Try Nurhayati ${ }^{1}$, Latifa Aini Susumaningrum ${ }^{1}$, Hanny Rasni ${ }^{1}$, Tantut Susanto ${ }^{1}$, \\ Diana Kholida ${ }^{2}$ \\ Fakultas Keperawatan, Universitas Jember \\ Pelayanan Sosial Tresna Werdha, Banyuwangi \\ email: tantut_s.psik@unej.ac.id
}

\author{
Artikel history \\ Dikirim, Jan $30^{\text {th }}, 2020$ \\ Ditinjau, Nov $11^{\text {th }}, 2020$ \\ Diterima, Nov $27^{\text {th }}, 2020$
}

\begin{abstract}
Elderly with hypertension have a higher of anxiety. Mental condition influence sleep patterns of elderly. The purpose of this study was to analyze the differenced anxiety and sleep patterns among elderly with hypertension and non-hypertension in nursing home (UPT PSTW) of Banyuwangi. A case-control design was used among 51 elderly (18 of control groups and 33 of case groups) using purposive sampling. A Geriatric Anxiety Inventory questionnaire was used to measure anxiety score of elderly, while Pittsburgh Sleep Quality Index questionnaire was used to measure sleep pattern. Chi-square test was used to analyze relationship between anxiety and sleep patterns among elderly with hypertension and non-hypertension. The results showed there were $57.6 \%$ of elderly with systolic hypertension having anxiety and $75.8 \%$ of elderly with systolic hypertension having poor sleep patterns. There were significantly differenced anxiety and sleep patterns between control and case groups $(p<0,05)$. However, level of anxiety and level of sleep pattern were more higher in case group compare to control groups $(p<0,05)$. The conclusion of this study, there is differenced anxiety and sleep patterns among elderly with hypertension and non hypertension. Therefore, elderly should more adaptive for mentainance of stressor and avoiding anxiety to reduce sleep disorder.
\end{abstract}

Keywords: Anxiety; Elderly; Hypertension; Sleep Pattern

\begin{abstract}
ABSTRAK
Lansia dengan hipertensi memiliki tingkat kecemasan yang lebih tinggi. Kondisi mental ini dapat mempengaruhi pola tidur pada lansia. Tujuan dari penelitian ini adalah untuk menganalisis perbedaan kecemasan dan pola tidur antara lansia dengan hipertensi dan tidak hipertensi di UPT PSTW Banyuwangi. Desain penelitian ini adalah case control dan peneliti menggunakan teknik purposive sampling dalam pengambilan datanya. Sampel dalam penelitian ini sebanyak 51 lansia (18 kelompok kontrol dan 33 kelompok kasus). Kuisioner Geriatric Anxiety Inventory digunakan untuk mengukur skor kecemasan lansia, sedangkan kuesioner Pittsburgh Sleep Quality Index digunakan untuk mengukur pola tidur lansia. Analisis hubungan kecemasan dan pola tidur pada lansia
\end{abstract}


hipertensi dan tidak hipertensi menggunakan Uji Chi Square dengan hasil penelitian menunjukkan bahwa terdapat $57,6 \%$ lansia dengan hipertensi sistolik mengalami kecemasan dan $75,8 \%$ lansia dengan hipertensi sistolik memiliki pola tidur yang buruk. Ada perbedaan kecemasan dan pola tidur yang signifikan antara kelompok kontrol dan kelompok kasus dimana tingkat kecemasan dan tingkat pola tidur lebih tinggi pada kelompok kasus dibandingkan dengan kelompok kontrol ( $p<0,05)$. Kesimpulan penelitian ini yaitu ada perbedaan kecemasan dan pola tidur antara lansia dengan hipertensi dan tidak hipertensi. Karena itu, lansia harus lebih adaptif untuk menghadapi stresor dan menghindari kecemasan untuk mengurangi gangguan tidur.

Kata Kunci: Kecemasan; Lansia; Hipertensi; Pola Tidur

\section{PENDAHULUAN}

Lansia adalah seseorang yang sudah mencapai usia $\geq 60$ tahun. Tahun 2019, Indonesia memasuki era penduduk menua (aging population) yang mana terdapat peningkatan jumlah lansia. Jumlah lansia pada tahun 2019 tercatat sebanyak 25,9 juta jiwa $(9,7 \%)$ dan diperkirakan akan terus meningkat hingga 48,2 juta lansia $(15,77 \%)$ di tahun 2035 (Kemenkes, 2019). Lansia pada umumnya akan menderita penyakit tidak menular atau non-communicable disease (NcDs), salah satu penyakit terbanyak yang dialami lansia adalah hipertensi (BKKBN, 2019). Hipertensi adalah peningkatan tekanan darah secara persisten dimana nilai sistol lebih dari $140 \mathrm{mmHg}$ dan nilai diastol lebih dari 90 mmHg (Ratnawati, 2017).

Hipertensi menjadi salah satu penyakit yang serius baik di Indonesia maupun di Dunia. Hipertensi biasa disebut dengan The Silent Killer karena tidak memunculkan gejala (Anwari dkk., 2018). Berdasarkan data World Health Organization (WHO) ada sebanyak 1,13 Miliar jiwa di dunia yang mengalami hipertensi dan jumlah hipertensi di Indonesia dengan usia 55-64 tahun memiliki proporsi sebanyak 55,2\% (Kemenkes RI, 2019). Peningkatan tekanan darah pada lansia dipengaruhi oleh adanya perubahan pada sistem kardiovaskuler lansia seperti peningkatan massa jantung, hipertrofi pada ventrikel dan penurunan kemampuan peregangan jantung (Azizah, 2011). Pan et al. (2015) melaporkan bahwa individu dengan hipertensi memiliki skor kecemasan yang lebih tinggi jika dibandingkan dengan individu yang tidak memiliki hipertensi. Kecemasan merupakan reaksi yang normal terhadap stress dan ancaman bahaya (Priyoto, 2015). 
Kecemasan yang dialami oleh lansia dengan hipertensi dihubungkan dengan adanya komplikasi hipertensi seperti stroke, gagal ginjal serta penyakit jantung yang berdampak pada terjadinya kematian sehingga lansia menganggap hal tersebut merupakan ancaman yang membahayakan kehidupannya (Ridwan dkk., 2017). Gejala klinik yang timbul antara lain rasa takut, rasa tegang, gelisah, hiperventilasi, sakit kepala, rasa capek, sulit tidur dan lain-lain. Sulit tidur menjadi salah satu dampak kecemasan yang dapat berpengaruh pada pola tidur lansia (Panjaitan, 2009 ; Witriya dkk., 2016).

Tidur merupakan proses yang dibutuhkan seseorang agar otak berfungsi dengan baik. Lansia membutuhkan waktu tidur 7,5 hingga 8 jam perhari (Priyoto, 2015). Gangguan pola tidur menyebabkan perubahan pada kualitas dan kuantitas tidur sehingga mengganggu kenyamanan lansia. Pola tidur yang terganggu akan menyebabkan munculnya kondisi seperti rentan terhadap penyakit, konfusi, demensia, disorientasi, gangguan atensi, penurunan kemampuan berkonsentrasi serta penurunan kemampuan beraktivitas (Witriya dkk., 2016). Oleh karena itu tujuan penelitian ini adalah untuk menganalisis hubungan kecemasan dengan pola tidur lansia hipertensi dan tidak hipertensi di UPT PSTW Kabupaten Banyuwangi.

Penelitian ini dianggap penting karena kita dapat mengetahui bagaimana gambaran kecemasan yang mempengaruhi pola tidur pada lansia hipertensi dan perbandingannya dengan lansia yang tidak hipertensi. Terdapat salah satu penelitian yang sudah melakukan penelitian mengenai hubungan tingkat kecemasan dengan kualitas tidur pada lansia hipertensi yaitu oleh Ramadan dkk. (2019) dimana dalam hasil penelitiannya menunjukkan bahwa kecemasan berhubungan dengan kualitas tidur pada lansia hipertensi namun penelitian tersebut tidak menyertakan perbandingannya dengan lansia yang tidak hipertensi sehingga peneliti ingin menunjukkan bagaimana hubungan kecemasan dengan pola tidur pada dua kelompok sekaligus yaitu kelompok lansia dengan hipertensi dan tidak hipertensi.

\section{METODE}

Penelitian ini berlokasi di UPT PSTW Kabupaten Banyuwangi dan proses 
pengambilan dilakukan pada bulan yaitu purposive sampling dimana Desember 2019. Penelitian ini peneliti menetapkan kriteria inklusi dan merupakan penelitian kuantitatif dan kriteria eksklusi.

bersifat non-eksperimental dengan menggunakan desain case control. Peneliti melakukan screening dengan Peneliti melakukan analisis hubungan kecemasan dengan pola tidur pada dua kelompok yakni kelompok lansia hipertensi dan tidak hipertensi di UPT PSTW Kabupaten Banyuwangi dan peneliti akan membandingkan hasil akhir dari analisis hubungan pada dua kelompok. Variabel kecemasan sebagai variabel independen dan pola tidur sebagai variabel dependen. Populasi dalam penelitian ini yaitu seluruh lansia yang tinggal di UPT PSTW Kabupaten Banyuwangi sebanyak 70 lansia. Teknik pengambilan responden yang digunakan pemeriksaan tekanan darah dan peneliti mengelompokkan lansia menjadi dua kelompok yaitu kelompok hipertensi dan tidak hipertensi. Peneliti membagikan lembar kuesioner Mini Mental Examination (MMSE) untuk melihat status mental lansia. Setelah proses screening pada 70 lansia, peneliti mendapatkan 51 responden dan 19 lansia lainnya tidak mengikuti penelitian karena tidak termasuk dalam kriteria inklusi penelitian. Adapun alur pengambilan sampel penelitian digambarkan pada gambar 1 berikut :

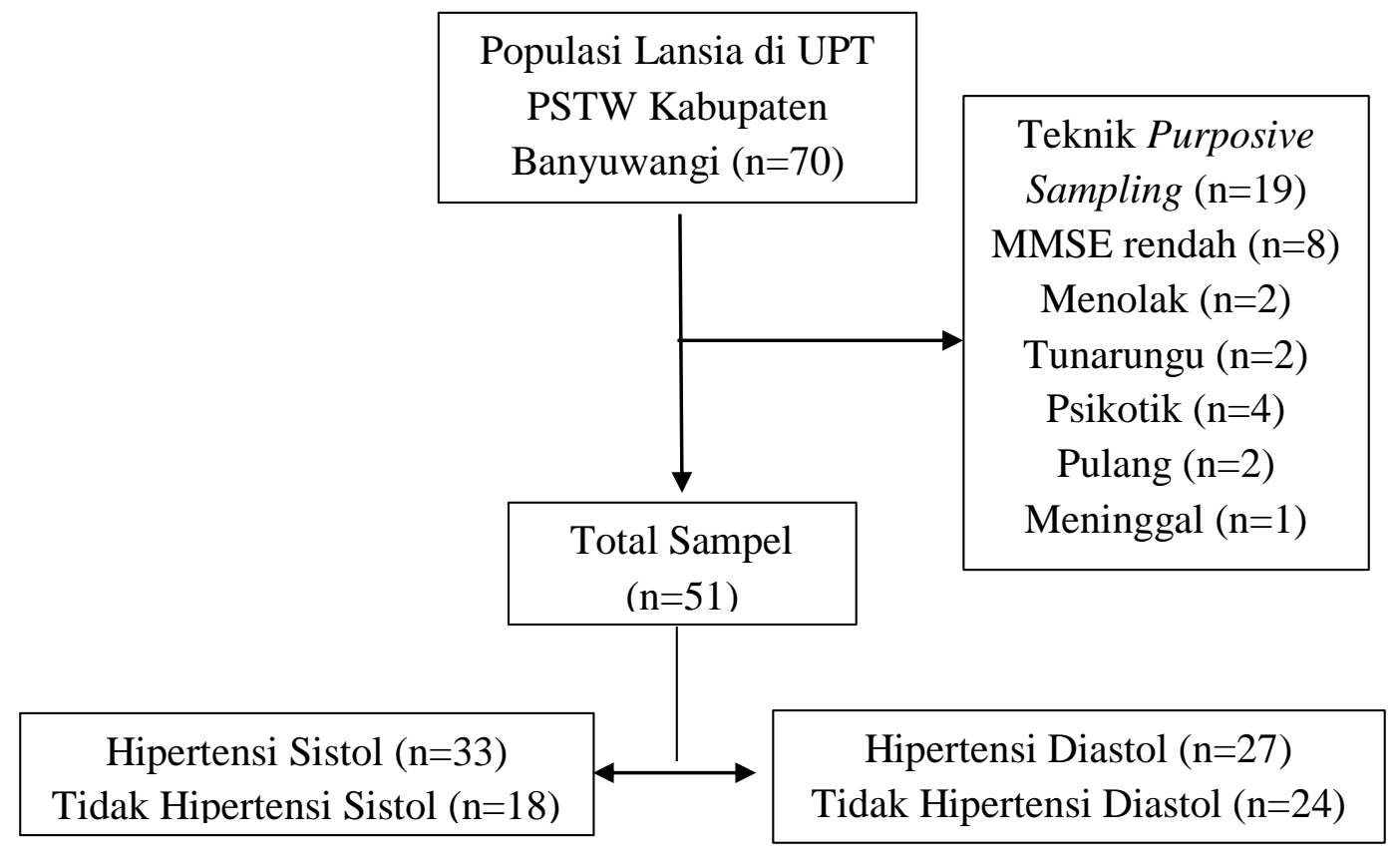

Gambar 1. Alur Pengambilan Sampel Penelitian 
Setelah responden sudah terpenuhi peneliti memulai untuk membagikan lembar informed consent, lembar kuesioner karakteristik lansia, kuesioner Geriatric Anxiety Inventory (GAI) untuk mengukur variable kecemasan dan kuesioner Pittsburgh Sleep Quality Index (PSQI) untuk mengukur variable pola tidur. Kuesioner Geriatric Anxiety Inventory (GAI) terdiri dari 20 item pernyataan dengan dua pilihan jawaban yaitu setuju dan tidak setuju. Untuk masing-masing jawaban dalam satu item pernyataan diber skor 1 . Skor setuju dari seluruh pernyataan kemudian dijumlahkan untuk mendapatkan skor total. Total skor kemudian digunakan untuk menginterpretasikan hasil. Untuk skor 0-8 berarti tidak ada kecemasan klinis yang signifikan dan skor 9-20 berarti ada kecemasan signifikan secara klinis Kuesioner GAI (Geriatric Anxiety Inventory) memiliki nilai spesifisitas $84 \%$ dan sensitivitas $75 \%$ dan nilai $\alpha$ Cronbach adalah 0,91 (Pachana et al., 2007).

Kesioner Pittsburgh Sleep Quality Index (PSQI) memiliki 18 pertanyaan yang mana pertanyaannya dikelompokkan menjadi tujuh komponen seperti kualitas tidur subyektif, latensi tidur, durasi tidur, efisiensi kebiasaan tidur, gangguan tidur, penggunaan obat tidur dan daytime disfunction. Skor jangkauan dari kuesioner PSQI yaitu pada skor 0-21 dimana skor 0 dianggap baik dan skor 21 dianggap buruk. Interpretasi totalnya yaitu jika nilai $\leq 5$ artinya pola tidur baik dan jika nilai >5 maka pola tidur buruk (Buysse et al., 1988). Pada kuesioner PSQI (Pittsburgh Sleep Quality Index) dalam versi bahasa Indonesia menunjukan nilai validitas 0,89 . Nilai reliabilitas kuesioner PSQI (Pittsburgh Sleep Quality Index) menunjukkan angka 0,79 (Alim, 2015).

Penelitian ini telah memenuhi uji etik yang diajukan pada Fakultas Kedokteran Gigi Universitas Jember dengan No. 664/UN25.8/KEPK/DL/ 2019. Peneliti menggunakan uji beda Independen Sample T-test untuk mencari nilai mean dari karakteristik usia dan karakteristik lainnya seperti jenis kelamin, tingkat pendidikan dan status pernikahan dihubungkan dengan kasus hipertensi menggunakan uji statistik Chi-Square. Peneliti melakukan analisis hubungan variabel kecemasan dengan variabel pola menggunakan uji statistik Chi-Square dengan tingkat signifikansi 0,05 dimana dasar pengambilan keputusan didapatkan 
apabila nilai $p$ value $<0,05$ maka Ho ditolak dan apabila nilai $p$ value $>0,05$ maka Ho diterima (Sujarweni, 2015).

\section{HASIL DAN PEMBAHASAN}

Penelitian ini menunjukkan bahwa dari total 51 lansia di UPT PSTW Kabupaten Banyuwangi terdapat 33 lansia yang mengalami hipertensi sistol dan 27 lansia mengalami hipertensi diastol. Gambaran karakteristik Lansia di UPT PSTW Kabupaten Banyuwangi ditunjukkan pada tabel 1 dan dihasilkan bahwa tidak ada perbedaan karakteristik lansia baik pada aspek usia, jenis kelamin, tingkat pendidikan dan status pernikahan dengan kejadian hipertensi ( $p$ value > 0,05) sehingga dapat disimpulkan bahwa data karakteristik lansia dengan hipertensi dan tidak hipertensi bersifat homogen.

Tabel 1. Karakteristik Lansia di UPT PSTW Kabupaten Banyuwangi.

\begin{tabular}{|c|c|c|c|c|c|c|c|c|}
\hline \multirow{3}{*}{$\begin{array}{l}\text { Karakteristik } \\
\text { Lansia }\end{array}$} & \multicolumn{2}{|c|}{ Sistol } & \multirow{3}{*}{$X^{2}$} & \multirow{3}{*}{$\begin{array}{c}p \\
\text { value }\end{array}$} & \multicolumn{2}{|c|}{ Diastol } & \multirow{3}{*}{$X^{2}$} & \multirow{3}{*}{$\begin{array}{c}p \\
\text { value }\end{array}$} \\
\hline & $\begin{array}{l}\geq 140 \\
\mathrm{mmHg}\end{array}$ & $\begin{array}{l}<140 \\
\mathrm{mmHg}\end{array}$ & & & $\begin{array}{l}\geq 90 \\
\mathrm{mmHg}\end{array}$ & $\begin{array}{l}<90 \\
\mathrm{mmHg}\end{array}$ & & \\
\hline & $M \pm S D$ & $M \pm S D$ & & & $M \pm S D$ & $M \pm S D$ & & \\
\hline Usia & $70 \pm 7,2$ & $68 \pm 8$ & - & 0,836 & $69 \pm 7,3$ & $69 \pm 7,7$ & - & 0,720 \\
\hline $\begin{array}{l}\text { Karakteristik } \\
\text { Lansia }\end{array}$ & $\mathrm{n}(\%)$ & $\mathrm{n}(\%)$ & $X^{2}$ & $\begin{array}{c}p \\
\text { value }\end{array}$ & $\mathrm{n}(\%)$ & $\mathrm{n}(\%)$ & $X^{2}$ & \\
\hline \multicolumn{9}{|l|}{ Jenis Kelamin } \\
\hline $\begin{array}{l}\text { Perempuan } \\
\text { Laki-laki }\end{array}$ & $\begin{array}{l}20(60,6) \\
13(39,4)\end{array}$ & $\begin{array}{l}11(61,1) \\
7(38,9)\end{array}$ & 0,00 & 1,000 & $\begin{array}{l}14(51,9) \\
13(48,1)\end{array}$ & $\begin{array}{l}17(70,8) \\
7(29,2)\end{array}$ & 1,20 & 0,272 \\
\hline \multicolumn{9}{|l|}{ Tingkat pendidikan } \\
\hline $\begin{array}{l}\text { Tamat SD } \\
\text { Tamat SLTP/ }\end{array}$ & $28(84,8)$ & $14(77,8)$ & 2,69 & 0,442 & $22(81,5)$ & $20(83,3)$ & 2,13 & 0,547 \\
\hline $\begin{array}{l}\text { Sederajat } \\
\text { Tamat SLTA/ }\end{array}$ & $2(6,1)$ & $3(16,7)$ & & & $2(7,4)$ & $3(12,5)$ & & \\
\hline $\begin{array}{l}\text { Sederajat } \\
\text { Perguruan }\end{array}$ & $1(3,0)$ & $1(5,6)$ & & & $1(3,7)$ & $1(4,2)$ & & \\
\hline Tinggi/Akademi & $2(6,1)$ & $0(0)$ & - & 1,000 & $2(7,4)$ & $0(0)$ & - & 1,000 \\
\hline $\begin{array}{l}\text { Status Pernikahan } \\
\text { Janda/Duda/ }\end{array}$ & & & & & & & & \\
\hline $\begin{array}{l}\text { Tidak Menikah } \\
\text { Menikah }\end{array}$ & $32(97,0)$ & $17(94,4)$ & & & $26(96,3)$ & $23(95,8)$ & & \\
\hline & $1(3,0)$ & $1(5,6)$ & & & $1(3,7)$ & $1(4,2)$ & & \\
\hline
\end{tabular}

Gambaran kecemasan lansia hipertensi dan tidak hipertensi di UPT PSTW Kabupaten Banyuwangi ditunjukkan pada tabel 2 dan dihasilkan bahwa tidak ada perbedaan antara tingkat kecemasan dengan kejadian hipertensi ( $p$ value > 0,05) sehingga dapat disimpulkan bahwa kecemasan dengan hipertensi dan tidak hipertensi bersifat homogen. 
Tabel 2. Kecemasan Lansia Hipertensi dan Tidak Hipertensi Di UPT PSTW Kabupaten Banyuwangi

\begin{tabular}{|c|c|c|c|c|c|c|c|c|}
\hline \multirow[t]{2}{*}{ Kecemasan } & \multicolumn{2}{|c|}{ Sistol } & \multirow[b]{2}{*}{$X^{2}$} & \multirow[b]{2}{*}{$\begin{array}{c}p \\
\text { value }\end{array}$} & \multicolumn{2}{|c|}{ Diastol } & \multirow[b]{2}{*}{$X^{2}$} & \multirow[b]{2}{*}{$\begin{array}{c}p \\
\text { value }\end{array}$} \\
\hline & $\begin{array}{c}\begin{array}{c}\geq 140 \\
\mathrm{mmHg}\end{array} \\
\mathrm{n}(\%)\end{array}$ & $\begin{array}{c}\begin{array}{c}<140 \\
\mathrm{mmHg}\end{array} \\
\mathrm{n}(\%)\end{array}$ & & & $\begin{array}{c}\geq 90 \\
\mathrm{mmHg}\end{array}$ & $\begin{array}{c}<90 \\
\mathrm{mmHg} \\
\mathrm{n}(\%)\end{array}$ & & \\
\hline \multicolumn{9}{|l|}{ Ada } \\
\hline Kecemasan & $19(57,6)$ & $7(38,9)$ & \multirow{4}{*}{0,966} & \multirow{4}{*}{0,326} & $14(51,9)$ & $12(50,0)$ & \multirow{4}{*}{0,000} & \multirow{4}{*}{1,000} \\
\hline Tidak Ada & & & & & & & & \\
\hline Kecemasan & $14(42,4)$ & $11(61,1)$ & & & $13(48,1)$ & $12(50,0)$ & & \\
\hline Total & $33(100)$ & $18(100)$ & & & $27(100)$ & $24(100)$ & & \\
\hline
\end{tabular}

Gambaran pola tidur lansia hipertensi

dengan kejadian hipertensi $(p$ dan tidak hipertensi di UPT PSTW value $=0,008$ dan $p$ value $=0,532$ ) Kabupaten Banyuwangi ditunjukkan sehingga dapat disimpulkan bahwa pola pada tabel 3 dan dihasilkan bahwa ada tidur dengan hipertensi dan tidak perbedaan nilai $p$ value antara pola tidur hipertensi bersifat tidak homogen.

Tabel 3. Pola Tidur Lansia Hipertensi Dan Tidak Hipertensi Di UPT PSTW Kabupaten Banyuwangi

\begin{tabular}{|c|c|c|c|c|c|c|c|c|}
\hline \multirow[t]{2}{*}{ Pola Tidur } & \multicolumn{2}{|c|}{ Sistol } & \multirow[b]{2}{*}{$X^{2}$} & \multirow[b]{2}{*}{$\underset{\text { value }}{p}$} & \multicolumn{2}{|c|}{ Diastol } & \multirow[b]{2}{*}{$X^{2}$} & \multirow[b]{2}{*}{$\begin{array}{c}p \\
\text { value }\end{array}$} \\
\hline & $\begin{array}{l}\geq 140 \\
\mathrm{mmHg}\end{array}$ & $\begin{array}{c}\begin{array}{c}<140 \\
\mathrm{mmHg}\end{array} \\
\mathrm{n}(\%)\end{array}$ & & & $\begin{array}{c}\begin{array}{c}\geq 90 \\
\mathrm{mmHg}\end{array} \\
\mathrm{n}(\%)\end{array}$ & $\begin{array}{c}\begin{array}{c}<90 \\
\mathrm{mmHg}\end{array} \\
\mathrm{n}(\%)\end{array}$ & & \\
\hline $\begin{array}{l}\text { Pola Tidur } \\
\text { Buruk } \\
\text { Pola Tidur }\end{array}$ & $25(75,8)$ & $6(33,3)$ & 7,104 & 0,008 & $18(66,7)$ & $13(54,2)$ & 0,391 & 0,532 \\
\hline Baik & $8(24,2)$ & $12(66,7)$ & & & $9(33,3)$ & $11(45,8)$ & & \\
\hline Total & $33(100)$ & $13(100)$ & & & $27(100)$ & $24(100)$ & & \\
\hline
\end{tabular}

Berdasarkan tabel 4 dan tabel 5 dapat dilihat jika ada hubungan antara kecemasan dengan pola tidur pada lansia dengan hipertensi dan lansia tidak hipertensi di UPT PSTW Kabupaten
Banyuwangi ( $p$ value $<0,05$ ) sehingga dapat disimpulkan bahwa kecemasan dengan pola tidur lansia hipertensi dan tidak hipertensi bersifat homogen. 
Tabel 4. Analisis Hubungan Kecemasan dengan Pola Tidur Lansia Hipertensi di UPT PSTW Kabupaten Banyuwangi

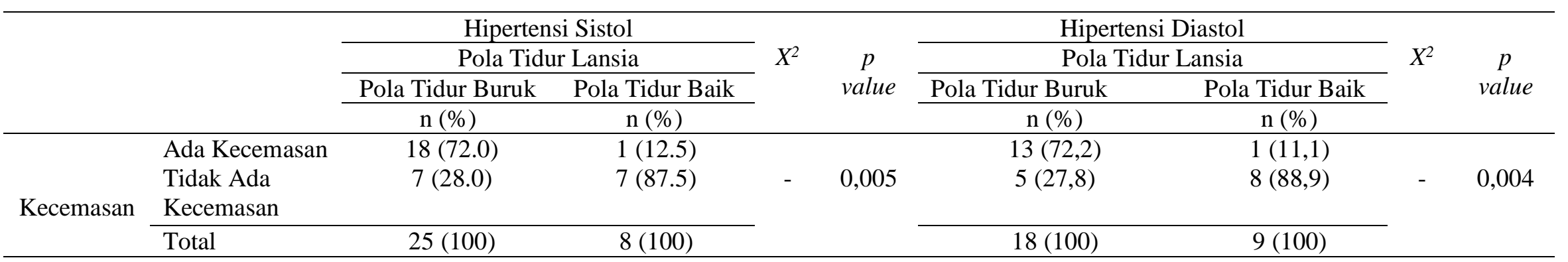

Tabel 5. Analisis Hubungan Kecemasan dengan Pola Tidur Lansia Tidak Hipertensi di UPT PSTW Kabupaten Banyuwangi

\begin{tabular}{|c|c|c|c|c|c|c|c|c|c|}
\hline & & \multirow{2}{*}{\multicolumn{2}{|c|}{$\begin{array}{c}\text { Tidak Hipertensi Sistol } \\
\text { Pola Tidur Lansia }\end{array}$}} & \multirow{4}{*}{$X^{2}$} & \multirow{4}{*}{$\begin{array}{c}p \\
\text { value }\end{array}$} & \multirow{2}{*}{\multicolumn{2}{|c|}{$\begin{array}{c}\text { Tidak Hipertensi Diastol } \\
\text { Pola Tidur Lansia }\end{array}$}} & \multirow{4}{*}{$X^{2}$} & \multirow{4}{*}{$\begin{array}{c}p \\
\text { value }\end{array}$} \\
\hline & & & & & & & & & \\
\hline & & Pola Tidur Buruk & Pola Tidur Baik & & & Pola Tidur Buruk & Pola Tidur Baik & & \\
\hline & & $\mathrm{n}(\%)$ & $\mathrm{n}(\%)$ & & & $\mathrm{n}(\%)$ & $\mathrm{n}(\%)$ & & \\
\hline \multirow{4}{*}{$\begin{array}{l}\text { Kecemasan } \\
\text { Lansia }\end{array}$} & Ada Kecemasan & $5(83,3)$ & $2(16,7)$ & & & $10(76,9)$ & $2(18,2)$ & \multirow{4}{*}{$\begin{array}{c}6,04 \\
2\end{array}$} & \multirow{4}{*}{0,014} \\
\hline & Tidak Ada & $1(16,7)$ & $10(83,3)$ & - & 0,013 & $3(23,1)$ & $9(81,8)$ & & \\
\hline & Kecemasan & & & & & & & & \\
\hline & Total & $6(100)$ & $12(100)$ & & & $13(100)$ & $11(100)$ & & \\
\hline
\end{tabular}

Berdasarkan hasil analisis pada tabel 1 menunjukkan bahwa tidak ada perbedaan nilai rata-rata usia lansia hipertensi dan tidak hipertensi. Pernyataan ini sejalan dengan penelitian yang dilakukan oleh Susanto et al. (2019) yang menyatakan bahwa tidak ada perbedaan nilai mean dari lansia dengan hipertensi dan tidak hipertensi ( $p$ value > 0,05). Wallace (2009) mengatakan bahwa hipertensi adalah salah satu penyakit kardiovaskuler yang umum dialami oleh lansia. (Yunanto dkk., 2020) juga menyebutkan bahwa usia menjadi faktor resiko penting dan berkontribusi pada prevalensi hipertensi dimana pada proses penuaan akan menyebabkan pembuluh darah menjadi kaku dan tidak elastis lagi. Hal tersebut dikarenakan adanya pertambahan kolagen sehingga 
terjadi penebalan struktur pada dinding arteri dan mengakibatkan penurunan rekoil pada siklus jantung (Lionakis et al., 2012). Selain itu peningkatan usia dapat menyebabkan terjadinya pembesaran dan penegangan arteri sehingga terjadi peningkatan kecepatan darah dari aorta ke sistem arteri sistemik (Mauk, 2006). Oleh karena itu dapat disimpulkan bahwa peningkatan tekanan darah pada lansia diakibatkan oleh perubahan pada sistem kardiovaskular seiring dengan pertambahan usia.

Karakteristik jenis kelamin tidak berhubungan dengan kejadian hipertensi pada lansia di UPT PSTW Kabupaten Banyuwangi ( $p$ value $>0,05$ ). Pernyataan ini sejalan dengan penelitian yang dilakukan oleh Sari (2016) yang menyatakan bahwa tidak ada hubungan yang signifikan antara jenis kelamin dengan adanya peningkatan tekanan darah ( $p$ value=0,130). Namun jika dilihat dari hasil penelitian ini jumlah lansia dengan hipertensi sistol dan diastol lebih banyak dialami oleh lansia dengan jenis kelamin perempuan dibandingkan dengan lansia dengan jenis kelamin lakilaki. Hal tersebut dikarenakan perempuan dengan lanjut usia akan mengalami proses menopause yang menyebabkan munculnya disfungsi endotel, peningkatan kekakuan arteri, peningkatan kolesterol total dan penurunan lipoprotein kepadatan tinggi (Lionakis et al., 2012). Oleh karena itu perubahan kondisi fisiologis akibat menopause membuat lansia perempuan lebih berisiko mengalami hipertensi jika dibandingkan dengan lansia laki-laki.

Penelitian ini menunjukkan bahwa tidak ada hubungan antara tingkat pendidikan dengan kejadian hipertensi sistol dan diastol pada lansia di UPT PSTW Kabupaten Banyuwangi ( $p$ value > 0,05). Penelitian ini sejalan dengan penelitian yang dilakukan oleh Chasanah dan Syarifah (2017) yang menyatakan bahwa tidak ada hubungan antara tingkat pendidikan dengan derajat tingkat hipertensi ( $p$ value=0,723). Lansia di UPT PSTW Kabupaten Banyuwangi yang memiliki hipertensi sistol dan diastol sebagian besar memiliki tingkat pendidikan yang rendah. Menurut Yang et al. (2017) lansia dengan tingkat pendidikan yang lebih rendah menunjukkan kontrol hipertensi yang kurang efisien. Tingkat pendidikan dikaitkan dengan kebiasaan gaya hidup sehat, tingkat kesadaran tentang kesehatan, kepatuhan dalam pengobatan 
sekaligus bagaimana pengontrolan hipertensi. Oleh karena itu dapat disimpulkan bahwa rendahnya tingkat pendidikan menyebabkan lansia kurang pengetahuan mengenai kebutuhan untuk berperilaku hidup sehat sehingga akan memicu timbulnya penyakit salah satunya hipertensi.

Penelitian ini menyebutkan tidak ada hubungan antara status pernikahan dengan terjadinya hipertensi pada lansia ( $p$ value $<0,05$ ). Pernyataan ini didukung oleh penelitian dari Suparti dan Handayani (2018) yang menunjukkan bahwa tidak ada hubungan antara status pernikahan dengan risiko terjadinya hipertensi pada lansia ( $p$ value $=0,034$ ). Lansia dengan hipertensi yang tinggal di UPT PSTW Kabupaten Banyuwangi mayoritas berstatus janda/duda/tidak menikah. Mekanisme yang mendasari adanya hubungan antara status pernikahan dengan kejadian hipertensi belum sepenuhnya dimengerti namun beberapa faktor yang dapat dihubungkan antara lain seperti faktor psikopatologis, jalur neuro endokrin dan perilaku kesehatan rendah (fisik, aktivitas, diet, kepatuhan pengobatan), mediator biologi dan berkaitan juga dengan sistem imun. Keterpisahan lansia dengan keluarganya dapat menyebabkan rasa kesepian dan stress yang berlebihan sehingga mengakibatkan timbulnya hipertensi

Berdasarkan hasil analisis pada tabel 2 menunjukkan bahwa lansia di UPT PSTW Kabupaten Banyuwangi dengan kelompok hipertensi dan tidak hipertensi sama-sama memiliki kecemasan dengan beberapa faktor pemicu yang mempengaruhinya. Stuart (2012) dalam Dariah dan Okatiranti (2015) menyatakan bahwa tingginya angka kecemasan disebabkan oleh beratnya beban yang dihadapi lansia seperti ancaman terhadap integritas fisik meliputi disabilitas fisiologis yang akan terjadi atau penurunan kemampuan untuk melakukan aktivitas hidup sehari-hari.

Penelitian ini menunjukkan bahwa terdapat 57,6\% lansia dengan hipertensi sistol dan 53,8\% lansia dengan hipertensi diastol memiliki kecemasan. Jumlah tersebut lebih besar jika dibandingkan dengan penelitian yang dilakukan oleh Ismail et al. (2015) yang menyatakan bahwa terdapat $13,3 \%$ lansia hipertensi dengan gejala kecemasan. Hal ini dikarenakan hipertensi merupakan salah satu penyakit yang dapat menimbulkan masalah baru seperti stroke, gagal 
jantung dan gagal ginjal sehingga mengarah pada ancaman kematian pada lansia (Laka dkk., 2018). Oleh karena itu lansia dengan hipertensi dianggap memiliki skor kecemasan yang lebih tinggi jika dibandingkan dengan lansia tidak hipertensi.

Berdasarkan hasil analisis pada tabel 3 menunjukkan adanya hubungan antara lansia yang memiliki hipertensi sistol dengan pola tidur yang buruk pada lansia. Hasil penelitian ini lebih besar jika dibandingkan dengan penelitian yang dilakukan oleh Martini dkk. (2018) yang menyatakan bahwa sebanyak 76,3\% dari responden yang mengalami hipertensi memiliki pola tidur yang lebih buruk. Hal ini disebabkan karena gejala akibat hipertensi dapat mengganggu tidur yang berdampak pada kualitas tidur (Lubis, 2013 ; Sakinah dkk., 2018). Adapun gejala yang muncul pada lansia hipertensi seperti sakit kepala, pusing, sesak nafas, obstructive sleep apnea syndrome (OSAS), dan nokturia sehingga dapat mengganggu pola tidur lansia (Crowin, 2001 ; Nuraini, 2015 ; Sakinah dkk., 2018). Oleh karena itu dapat disimpulkan jika lansia gangguan tidur yang dialami lansia diakibatkan oleh gejala hipertensi seperti seringnya terbangun pada malam hari, bangun terlalu dini dan nokturia.

Berdasarkan analisis penelitian pada tabel 4 dan tabel 5 menunjukkan bahwa ada hubungan antara kecemasan dengan pola tidur pada lansia dengan hipertensi dan lansia tidak hipertensi di UPT PSTW Kabupaten Banyuwangi ( $p$ value < 0,05). Pernyataan ini sejalan dengan penelitian yang dilakukan oleh Witriya dkk. (2016) yang menyatakan ada hubungan tingkat kecemasan dengan pola tidur lansia ( $p$ value $=0,00)$ dan penelitian yang dilakukan oleh Sincihu dkk. (2018) yang menyatakan bahwa terdapat hubungan antara tingkat kecemasan pada lansia dengan derajat keparahan insomnia ( $p$ value $=0,000)$. Hal tersebut dikarenakan faktor predisposisi dari faktor mental/emosional mungkin terkait dengan timbulnya masalah tidur (Reuben, et al., 2011; Tabloski, 2014).

Adapun mekanisme yang terlibat dalam gangguan kecemasan yaitu, adanya aktivasi fisiologis yang menyebabkan detak jantung meningkat, peningkatan tekanan darah, produksi kortisol, peningkatan kesadaran perseptual, pemrosesan kognitif yang cepat dan tanggapan motorik yang lebih cepat 
sehingga menimbulkan kurangnya kantuk pada lansia (Leblanc dkk., 2015) sehingga akan menyebabkan efisiensi tidur yang rendah, kualitas tidur yang buruk, bangun lebih sering, peningkatan latensi tidur/sulitnya memulai tidur, bangun lebih dini dan sering terbangun dimalam hari. Oleh karena itu dari hasil penelitian ini dapat disimpulkan bahwa lansia dengan kecemasan cenderung memiliki pola tidur yang buruk.

Penelitian ini memiliki keterbatasan berkaitan dengan minumnya jumlah responden dimana peneliti hanya mendapatkan 51 lansia. Hal ini dikarenakan jumlah populasi lansia yang ada di PSTW Kabupaten Banyuwangi hanya berjumlah 70. Peneliti juga melakukan screening untuk memperoleh sampel sesuai dengan kriteria inklusi yang telah ditetapkan serta terdapat beberapa lansia yang menolak untuk menjadi responden. Selain itu adanya proses pemeriksaan tekanan darah pada saat screening hanya dilakukan satu kali karena terkait dengan keterbatasan waktu penelitian sehingga diagnosis hipertensi ditegakkan pada saat proses pemeriksaan.

\section{SIMPULAN}

Kesimpulan dari penelitian ini adalah bahwa ada hubungan antara kecemasan dengan pola tidur pada lansia dengan hipertensi sistol $(p$ value $=0,005)$ dan hipertensi diastol ( $p$ value $=0,004)$ serta pada lansia yang tidak hipertensi sistol ( $p$ value $=0,013)$ dan tidak hipertensi diastol $\left(X^{2}=6,042 ; p\right.$ value $\left.=0,014\right) \mathrm{di}$ UPT PSTW Kabupaten Banyuwangi.

Peneliti menyarankan agar peneliti selanjutnya mengambil responden lebih banyak dengan melakukan penelitian pada wilayah komunitas atau meneliti lebih dari satu UPT PSTW (Pelayanan Sosial Tresna Werdha). Selain itu peneliti menyarankan agar peneliti selanjutnya melakukan penelitian terkait faktor-faktor pemicu terjadinya hipertensi pada lansia yang tinggal di UPT PSTW Kabupaten Banyuwangi.

\section{UCAPAN TERIMA KASIH}

Dalam penyusunan penelitian ini tidak lepas dari bantuan dari berbagai pihak. Oleh sebab itu peneliti menyampaikan terimakasih kepada Dekan Fakultas Keperawatan Universitas Jember, Departemen Komunitas Fakultas Keperawatan Universitas Jember dan Kelompok Riset Keperawatan Gerontik : 
Kesehatan dan Kesejahteraan Lanjut Usia (Healthy and Wellness of Elderly Studies), pihak UPT PSTW Kabupaten Banyuwangi, pihak akademik Fakultas Keperawatan Universitas Jember, lansia di UPT PSTW Kabupaten Banyuwangi serta semua pihak yang telah membantu dan berperan yang tidak dapat saya sebutkan satu-persatu.

\section{DAFTAR RUJUKAN}

Alim, I. Z. 2015. Uji Validitas Dan Reliabilitas Instrumen Pittsburgh Sleep Quality Index Versi Bahasa Indonesia $=$ Test Validity and Reliability of the Instrument Pittsburgh Sleep Quality Index Indonesia Language Version. Universitas Indonesia Library. (Online) (http://lib.ui.ac.id/detail?id $=20404062 \&$ lokasi=lokal) diakses pada Oktober 2019

Anwari, M., R. Vidyawati, R. Salamah, M. Refani, N. Winingsih, D. Yoga, R. Inna, dan T. Susanto. 2018. Pemberian senam antihipertensi sebagai upaya menstabilkan tekanan darah: studi kasus pada keluarga binaan di desa kemuningsari lor kecamatan panti kabupaten jember. The Indonesian Journal of Health Science. 165-168. (Online). (doi : https://doi.org/10.32528/ijhs.v0i0.1 542) diakses pada November 2019

\section{Azizah, L. M. 2011. Keperawatan Lanjut Usia. Edisi 1. Yogyakarta: Graha Ilmu. BKKBN. 2019. Info Demografi}

Buysse, D. J., C. F. Reynolds, T. H. Monk, S. R. Berman, dan D. J.
Kupfer. 1988. The pittsburgh sleep quality index: a new instrument psychiatric practice and research. Psychiatry Research. 28:193-213. (Online) (doi: 10.1016/01651781(89)90047-4) diakses pada Oktober 2019

Chasanah, S. U. dan N. Syarifah. 2017. Hubungan karakteristik individu penderita hipertensi dengan derajat hipertensi di puskesmas depok ii sleman yogyakarta. Jurnal Formil (Forum Ilmiah) KesMas Respati. 2(1):1-9. (Online) (doi: https://doi.org/10.35842/formil.v2i 1.57) diakses pada Januari 2020

Dariah, E. D. dan Okatiranti. 2015. Hubungan kecemasan dengan kualitas tidur lansia di posbindu anyelir kecamatan cisura kabupaten bandung barat. Jurnal Ilmu Keperawatan. 3(2):87-104. (Online) (doi: https://doi.org/10. 31311/.v3i2.156) diakses pada Oktober 2019

Ismail, Z., M. Mohamad, M. R. Isa, M. A. Fadzil, S. M. Yassin, K. T. Ma, dan M. H. bin A. Bakar. 2015. Factors associated with anxiety among elderly hypertensive in primary care setting. Journal of Mental Health. 24(1):29-32. (Online) (doi: 10.3109/09638237.2014.971148) diakses pada Oktober 2019

$\begin{array}{ccr}\text { Kementerian } & \text { Kesehatan } & \text { Republik } \\ \text { Indonesia. } & \text { 2019a. } & \text { Indonesia } \\ \text { Memasuki } & \text { Periode } & \text { Aging } \\ \text { Population } & & \end{array}$

Kementerian Kesehatan Republik Indonesia. 2019b. Hipertensi Penyakit Paling Banyak Diidap Masyarakat. www.depkes.go.id 
[Diakses pada September 1, 2019].

Laka, O. K., D. Widodo, dan W. R. H. 2018. Hubungan hipertensi dengan tingkat kecemasan pada lansia di posyandu lansia desa banjarejo kecamatan ngantang malang. Nursing News. 3(1):22-32. (Online) (https://publikasi.unitri.ac.id/index. php/fikes/article/view/749) diakses pada September 2019

Leblanc, M. F., S. Desjardins, dan A. Desgagné. 2015. Sleep problems in anxious and depressive older adults. Psychology Research and Behavior Management. 8:161-169. (Online) (doi: $\quad$ 10.2147/PRBM.S80642) diakses pada Oktober 2019

Lionakis, N., D. Mendrinos, E. Sanidas, G. Favatas, dan M. Georgopoulou. 2012. Hypertension in the elderly. World J Cardiol. 4(5):135-147. (Online) (doi: 10.4330/wjc. v4.15.135) diakses pada November 2019

Martini, S., S. Roshifanni, dan F. Marzela. 2018. Pola tidur yang buruk meningkatkan risiko hipertensi. Jurnal MKMI. 14(3):297-303. (Online) (doi: 10.30597/mkmi.v14i3.4181) diakses pada Januari 2020

Mauk, K. L. 2006. Gerontological Nursing (Competencies For Care). Edisi 1. Sadburry: Jones and Bartlett Publishers.

Pachana, N. A., G. J. Byrne, H. Siddle, N. Koloski, E. Harley, dan E. Arnold. 2007. Development and validation of the geriatric. International Psychogeriatrics. 19(1):103-114. (Online) (doi: 10.1017/S1041610206003504) diakses pada November 2019

Pan, Y., W. Cai, Q. Cheng, W. Dong, T. An, dan J. Yan. 2015. Association between anxiety and hypertension : a systematic review and metaanalysis of epidemiological studies. Neuropsychiatric Disease and Treatment. 11:1121-1130. (Online) (doi: 10.2147/NDT.S77710) di akses pada September 2019

Priyoto. 2015. Nursing Intervention Classification (NIC) Dalam Keperawatan Gerontik. Edisi 1. Jakarta Selatan: Penerbit Salemba Medika.

Ramadan, H., T. Puspita, P. Budhiaji, dan M. H. Sulhan. 2019. Hubungan tingkat kecemasan dengan kualitas tidur pada lansia penderita hipertensi. Jurnal Keperawatan 'Aisyiyah. 6(2):53-58. (Online) (doi:https://doi.org/10.33867/jka.v 6i2.141) diakses pada Oktober 2020

Ratnawati, E. 2017. Asuhan Keperawatan Gerontik. Edisi 1. Yogyakarta: Pustaka Baru Press.

Ridwan, D. Widodo, dan E. Widiani. 2017. Hubungan hipertensi dengan kecemasan pada lanjut usia di posyandu permadi kelurahan tlogomas kecamatan lowokwaru kota malang. Nursing News. 2(3):676-686. (Online) (https://publikasi.unitri.ac.id/index. php/fikes/article/view/704) diakses pada September 2019

Sakinah, P. R., C. E. Kosasih, dan E. A. Sari. 2018. Gambaran kualitas tidur pada penderita hipertensi. Media Kesehatan Politeknik Kesehatan Makassar. 13(2):46-52. (Online) (doi:https://doi.org/10.32382/medk 
es.v13i2.663) diakses pada Januari 2020

Sari, Y. K. 2016. Hubungan jenis kelamin dengan kejadian hipertensi pada lansia di puskesmas nglegok kabupaten blitar. Jurnal Ners Dan Kebidanan. 3(3):262-265. (Online) (https://jnk.phb.ac.id/index.php/jnk/ article/view/0139) diakses pada Januari 2020

Sincihu, Y., B. H. Daeng, dan P. Yola. 2018. Hubungan kecemasan dengan derajat insomnia pada lansia. Jurnal Ilmiah Kedokteran Wijaya Kusuma. 7(1):15-30. (Online) (doi: 10.30742/jikw.v7i1.91) diakses pada Januari 2020

Sujarweni, V. W. 2015. Statistik Untuk Kesehatan. Edisi 1. Yogyakarta: Penerbit Gava Media.

Suparti, S. dan D. Y. Handayani. 2018. Screening hipertensi pada lansia di wilayah puskesmas banyumas. Indonesian Journal for Health Sciences. 2(2):84-93. (Online) (doi: 10.24269/ijhs.v2i .875) diakses pada Januari 2020

Susanto, T., H. Rasny, L. A. Susumaningrum, R. A. Yunanto, dan K. R. M. Nur. 2019. Prevalence of hypertension and predictive factors of self-efficacy among elderly people with hypertension in institutional-based rehabilitation in indonesia. Kontakt. 21(1):14-21. (Online) (doi: 10.32725/kont. 2018.007) diakses pada Januari 2020

Tabloski, P. A. 2014. Gerontological Nursing. Edisi 3. New Jersey: Pearson Education.
Wallace, M. 2009. Essentials of Gerontological Nursing. Edisi 1. New York: Springer Publishing Company.

Witriya, C., N. W. Utami, dan M. Andinawati. 2016. Hubungan tingkat kecemasan dengan pola tidur lansia di kelurahan tlogomas kota malang. Nursing News. 1(2):190-203. (Online) (https://publikasi.unitri.ac.id/index. php/fikes/article/view/437) diakses pada September 2019

Yunanto, R. A., T. Susanto, H. Rasni, L. A. Susumaningrum, dan K. R. Muhammad Nur. 2020. Prevalence of hypertension and related factors among older people in nursing home of jember, east java, indonesia. NurseLine Journal. 4(2):146. (Online) (doi: https://doi.org/10. 19184/nlj.v4i2.14931) diakses pada Oktober 2020. 